Eur. J. Clin. Chem. Clin. Biochem.

Vol. 29, 1991, pp. 499-505

(C) 1991 Walter de Gruyter \& Co.

Berlin - New York

\title{
Characterization of a Gelatinase from Human Rheumatoid Synovial Fluid Cells
}

By H. Kolkenbrock ${ }^{1}$, H. M.-Ali ${ }^{2}$, Adelheid Hecker-Kia ${ }^{1}$, G. Buchlow ${ }^{1}$, H. Sörensen ${ }^{3}$, R. W. Hauer ${ }^{3}$ and N. Ulbrich ${ }^{1}$

1 Institut für Biochemie, Freie Universität Berlin

2 Institut für Anatomie, Freie Universität Berlin

3 Immanuel-Krankenhaus GmbH, Rheuma-Klinik, Berlin

(Received October 25, 1990/April 25, 1991)

Summary: A metalloproteinase with a specificity for gelatin was isolated from serum-free medium of cultures of rheumatoid synovial fluid. The enzyme showed all the properties of a leukocyte gelatinase. In addition to gelatin this proteinase cleaved the synthetic substrate dinitrophenyl-Pro-Gln-Gly-Ile-Ala-Gly-Gln-D-Arg (Dnp-peptide) rapidly, while casein was a much poorer substrate. This proteinase showed no enzymatic activity against collagen type $I$, was secreted in a latent form and could be activated by trypsin or organomercurial compounds, such as mersalylic acid or 4-aminophenylmercury acetate. The latent enzyme had an apparent molecular mass of 130000-150000 estimated by gel filtration or 97000 by electrophoresis on polyacrylamide gel containing sodium dodecyl sulphate. When analysed by immunoblotting the enzyme was recognized by antibodies raised against human polymorphonuclear leukocyte gelatinase. Although we found synovial fibroblasts to be largely present in the cell cultures we could not detect any fibroblast gelatinase activity.

\section{Introduction}

Three related neutral metalloproteinases - interstitial collagenase, gelatinase and stromelysin - are thought to play the major role in the degradation of the extracellular matrix compounds, collagen and proteoglycan. The classic vertebrate collagenases, now widely called interstitial collagenases (1), exhibit a high specificity for the interstitial collagen types I, II and III, but little catalytic activity for denatured collagen (gelatin), whereas gelatinases degrade all types of gelatin and show no activity against the interstitial collagens. However, in recent years it has been shown that gelatinases degrade collagen types IV, V, VII and XI (2-9). Collagenase and stromelysin as well as gelatinase are synthesized as latent enzymes. While the activation process in vivo is not fully understood, in vitro activation is achieved by the action of organomercurial compounds such as mersalylic acid or 4aminophenylmercuric acetate.
Essentially two forms of gelatinases have been described so far: gelatinases secreted from connective tissue cells (fibroblasts) predominantly show molecular masses of about 70000 , while circulating neutrophils, monocytes and macrophages secrete gelatinases of molecular masses $90000-97000(2-4,10-14)$. However, the molecular mass of a gelatinase isolated from human skin was $120000-150000$, as determined by gel filtration and about 100000 by polyacrylamide gel electrophoresis in the presence of sodium dodecyl sulphate (15).

In this study, we describe a gelatinase of human rheumatoid synovial fluid cells. While rheumatoid synovial cells derived from synovial tissue secrete a connective tissue gelatinase (16), the adherent cells, derived from synovial fluid, released a macrophagelike gelatinase. 


\section{Materials and Methods}

\section{Materials}

Rheumatoid synovia originating from patients of the RheumaKlinik, Immanuel-Krankenhaus, Berlin. Buffy coat was kindly supplied by Deutsches Rotes Kreuz, Berlin. Ultrogel AcA 44 and phorbol myristate acetate were purchased from Serva, Heidelberg (Germany). Gelatin-Sepharose was prepared in our laboratory. Sepharose 4-B was obtained from Pharmacia. Cyanogen bromide, gelatin, mersalylic acid, 4-aminophenylmercury acetate, goat anti-rabbit IgG peroxidase conjugate, 3-amino-9ethylcarbazole and molecular weight markers for polyacrylamide gel electrophoresis in the presence of sodium dodecyl sulphate were purchased from Sigma. The dinitrophenyl-peptide was obtained from Bachem, Heidelberg (Germany). Aprotinin was a gift of Dr. Herbert Wenzel, Bielefeld (Germany).

\section{Protein determination}

Protein concentrations were determined with the bichinchoninic acid reagent (Pierce, USA) with bovine albumin as standard.

\section{SDS-PAGE}

SDS polyaçrylamide gel electrophoresis was performed essentially as described (17)

\section{Immunoblotting}

For electroblotting the samples were transferred from the gel to Millipore Immobilon-membranes at $500 \mathrm{~mA}$ for $30 \mathrm{~min}$. The membranes were blocked, incubated with antiserum raised in rabbits against leukocyte gelatinase, followed by peroxidaselabelled anti-IgG. The reactive bands were visualized with 3 amino-9-ethylcarbazole.

\section{Enzyme assays}

Gelatinase activity was determined with the synthetic substrate $\mathrm{N}$-(2,4)-dinitrophenyl-Pro-Gln-Gly-Ile-Ala-Gly-Gln-DArg

(18). The activity against protein substrates, such as gelatin and casein, was determined with the fluorescamine method (19).

\section{Enzyme activation}

To activate latent gelatinase with organomercurial compounds, mersalylic acid or 4-aminophenylmercury acetate were added to the incubation mixture to give a final concentration of 1 and $1.5 \mathrm{mmol} / \mathrm{l}$ respectively. Due to its own fluorescence, 4-aminophenylmercury acetate is not suitable for the fluorescamine method. For the activation with trypsin, the latent enzyme was preincubated for $30 \mathrm{~min}$ with $10 \mu \mathrm{g}$ trypsin. Finally, trypsin was inhibited by the addition of $10 \mu \mathrm{g}$ aprotinin.

\section{Cell preparation and culture}

About $6 \mathrm{ml}$ rheumatoid synovial fluid in a culture flask $(25$ $\mathrm{cm}^{2}$ ) were allowed to stand at $37^{\circ} \mathrm{C}$ for 24 hours in an atmosphere of $0.05 \mathrm{CO}_{2}$ and 0.95 air. The synovial fluid was decanted from adherent cells and replaced by Dulbecco's modified Eagle's medium containing $100 \cdot 10^{3} \mathrm{U} / 1$ penicillin, $100 \mathrm{mg} / \mathrm{l}$ streptomycin, $1-2.5 \mathrm{mg} / \mathrm{l}$ amphotericin $\mathrm{B}$ and $0.3 \mathrm{~g} / \mathrm{l} L$-glutamine without serum. The medium was changed daily, and harvests of culture medium were pooled continuously from the second day until the gelatinase activity was $50 \mathrm{mU} / \mathrm{l}$. The pooled medium was stored at $-20^{\circ} \mathrm{C}$.

The determination of cell types was kindly carried out by Professor Merker, Institute for Anatomy, Freie Universität
Berlin. For this purpose $1 \mathrm{ml}$ of rheumatoid synovial fluid was cultivatedras described above on glass coverslips $\left(5 \mathrm{~cm}^{2}\right)$. These coverslips were fixed in $20 \mathrm{~g} / \mathrm{l}$ formaldehyde on day $1,2,3,4$, 5,6 and 7 after the start of cultivation and stained with $10 \mathrm{~g} / \mathrm{l}$ Giemsa-solution.

The following steps were carried out at $4^{\circ} \mathrm{C}$.

\section{Chromatography on Ultrogel AcA 44}

The crude gelatinase extract was concentrated by ultrafiltration (Amicon, YM30) and subjected to gel chromatography on an AcA 44 column $(2 \times 90 \mathrm{~cm})$, equilibrated in buffer $A(0.05$ $\mathrm{mol} / 1$ Tris- $\mathrm{HCl}, \mathrm{pH} 7.0,0.2 \mathrm{~mol} / 1 \mathrm{NaCl}, 0.005 \mathrm{~mol} / \mathrm{l} \mathrm{CaCl}, 0.5$ $\mathrm{g} / \mathrm{l} \mathrm{NaN}, 0.5 \mathrm{~g} / \mathrm{1}$ Brij 35).

\section{Chromatography on gelatin-Sepharose}

The gelatinase-containing fractions from AcA 44 were chromatographed on a gelatin-Sepharose column $(1 \times 5 \mathrm{~cm})$ equilibrated in buffer A. Elution of gelatinase was achieved with $0.05 \mathrm{~mol} / 1 \mathrm{Tris}-\mathrm{HCl}, \mathrm{pH} 7.0,1 \mathrm{~mol} / 1 \mathrm{NaCl}, 0.005 \mathrm{~mol} / 1 \mathrm{CaCl}_{2}$, $0.5 \mathrm{~g} / 1 \mathrm{NaN}_{3}, 0.5 \mathrm{~g} / \mathrm{l}$ Brij 35 containing $50 \mathrm{~g} / \mathrm{l}$ dimethyl sulphoxide (4).

\section{Preparation of leukocytes}

The leukocytes were prepared from buffy coat $(1000 \mathrm{ml}$, $4 \times 10^{10} / 1$ leukocytes) essentially as described (20).

\section{Phorbol-myristate-acetate stimulation}

The leukocytes were stimulated with phorbol myristate acetate essentially as described (4). The leukocyte sediment was suspended in $500 \mathrm{ml}$ Hank's medium, containing $\mathrm{Ca}^{2+}$ and $\mathrm{Mg}^{2+}$, at $37^{\circ} \mathrm{C}$. Exocytosis of latent gelatinase was induced by adding $10 \mu \mathrm{l}$ phorbol myristate acetate $(5 \mathrm{mg}$ phorbol myristate acetate in $1 \mathrm{ml}$ dimethyl sulphoxide) and gentle shaking for $20 \mathrm{~min}$. The cells were sedimented by centrifugation at $10000 \mathrm{~g}$ for $5 \mathrm{~min}$ and the supernatant, containing the gelatinase, was concentrated by ultrafiltration (Amicon, YM30).

\section{Results \\ Proteinase activity in cell culture medium}

Cell adhesion was achieved at more than $80 \%$ under the conditions employed (49 cases). Figure 1 shows the synovial cell monolayer culture at various times of cultivation. The adherent cells derived from rheumatoid synovial fluid on day 1 consisted predominantly of macrophages (60\%) and fibroblasts (20\%) and about $20 \%$ of partly degenerating granulocytes. The proportion of fibroblasts increases continuously from about $20 \%$ (day 2) to about $70 \%$ (day 7), whereas the macrophages decreased from approximately $80 \%$ on day 2 to $30 \%$ on day 7 . After the second day granulocytes were no longer observed.

In the rheumatoid synovial fluids as well as in the - media of the adherent synovial cells we found a metaldependent proteinase activity against the dinitrophenylpeptide. In the synovial flưĭd and in the initial me- 


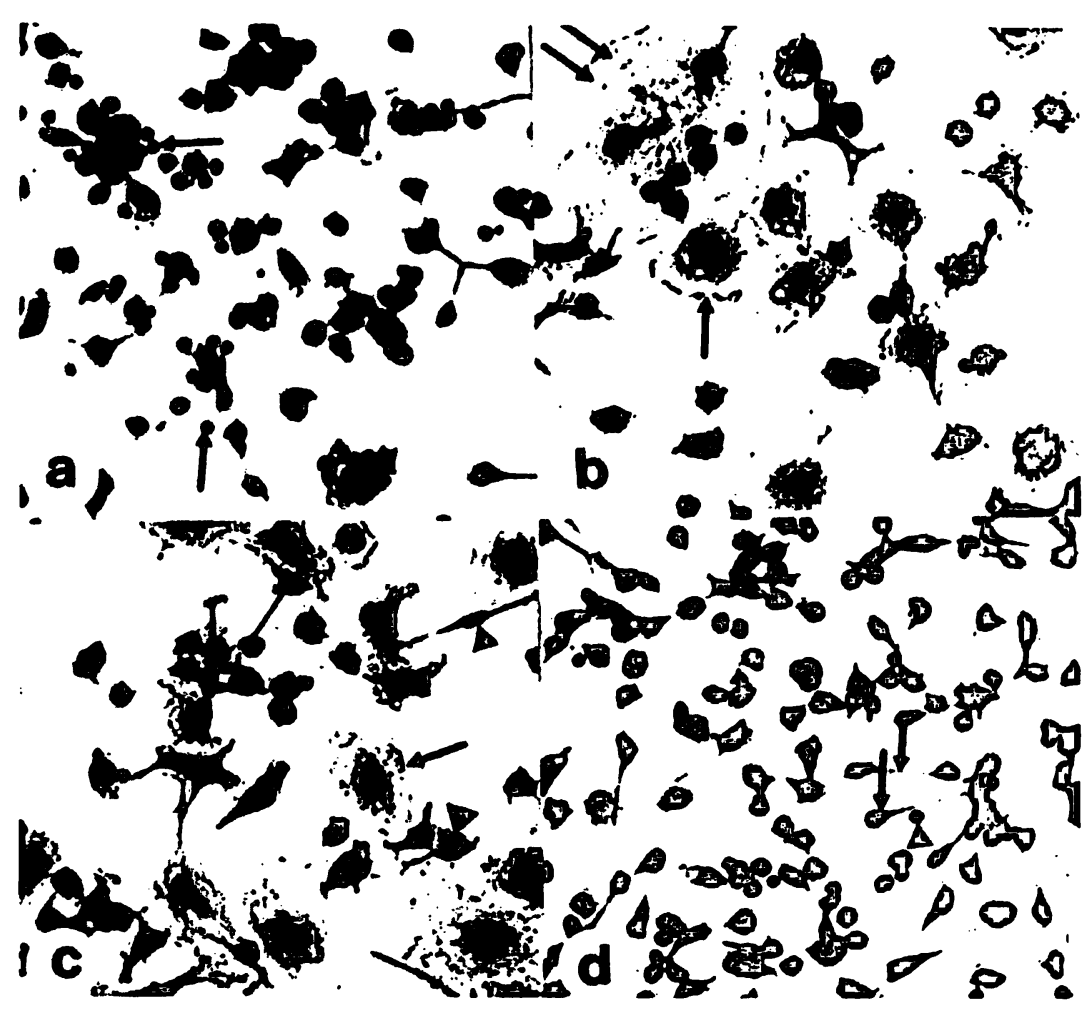

Fig. 1. Photomicrographs $(\times 200)$ of synovial fluid cell-monolayer;

a) after 1 day of cultivation: fibroblasts, macrophages and small, round, partly degenerated granulocytes (marked by arrows);

b) after 3 days of cultivation: fibroblasts and many macrophages (marked by an arrow). A giant macrophage is marked by a double arrow;

c) after 5 days of cultivation: fibroblasts (marked by an arrow head) and macrophages (marked by an arrow);

d) after 7 days of cultivation: predominantly fibroblasts (marked by an arrow). Small nuclei (arrow head) indicate the beginning of cell necrosis.

dium (24 hours in culture) this activity was not necessarily latent, but often predominantly in an active form (data not shown), and could be attributed to several proteinases, whereas the activity in the later media (48 hours in culture) was at least $90 \%$ latent in all cases. From the third day onwards, no other activity than the latent activity could be detected. Chromatography on Ultrogel AcA 44 of several individual media showed that a single proteinase was responsible for the latent activity.

The gelatinolytic activity found in the media of various cell cultures differed considerably. In a few cases the activity decreased rapidly within two or three days to below $50 \mathrm{mU} / 1$. More typically, the activity, which differed considerably between cultures, decreased more slowly (fig. 2).

\section{Gelatinase isolation}

The gelatinase from the culture medium conditioned by the human rheumatoid synovial cells was purified by gel chromatography on Ultrogel AcA 44, followed by affinity chromatography on gelatin-Sepharose (figs. 3 and 4). The steps of purification are illustrated

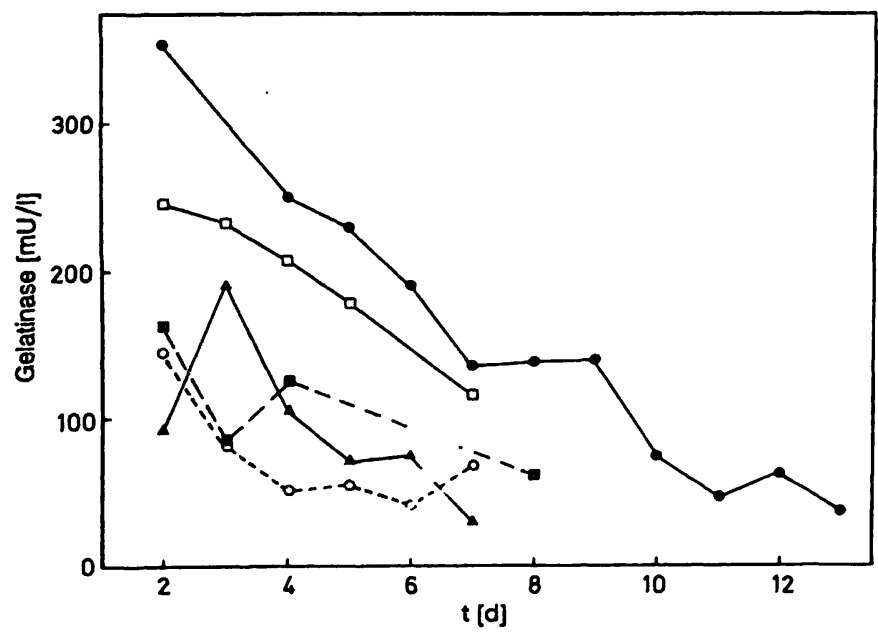

Fig. 2. Time course of dinitrophenyl-peptide hydrolysis by a gelatinase in five different culture media of rheumatoid synovial fluid cells. The media were changed daily.

(tab. 1). For comparison, we purified the gelatinase from phorbol ester-stimulated human polymorphonuclear leukocytes essentially in the same way. Both gelatinases were eluted from the AcA 44 column with a relative molecular mass of $130000-150000$. The 


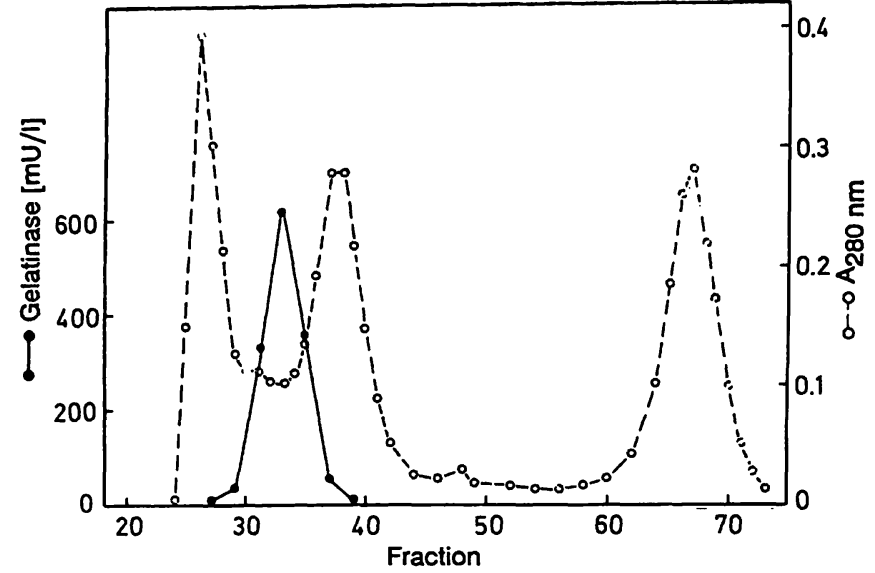

Fig. 3. Gel filtration on Ultrogel AcA 44. Culture supernatants $(57 \mathrm{ml})$, concentrated 10 fold by pressure dialysis, were applied to an Ultrogel AcA 44 column $(2 \times 90 \mathrm{~cm})$, equilibrated in $0.05 \mathrm{~mol} / 1$ Tris- $\mathrm{HCl}, \mathrm{pH} 7.0,0.2 \mathrm{~mol} / 1$ $\mathrm{NaCl}, 0.005 \mathrm{~mol} / \mathrm{l} \mathrm{CaCl}, 0.5 \mathrm{~g} / 1 \mathrm{Brij} \mathrm{35,} 0.5 \mathrm{~g} / \mathrm{l} \mathrm{NaN}$. Fraction volume $4.8 \mathrm{ml}$.

specific activity of the polymorphonuclear leukocyte gelatinase is about five times higher than the gelatinase isolated from synovial fluid cells, probably due to the higher purity of the enzyme preparation from leukocytes.

\section{SDS-PAGE and immunoblotting}

The purified gelatinases from rheumatoid synovial fluid cells and from human neutrophil granulocytes, respectively, showed the same relative molecular mass of about 95000 in polyacrylamide gel electrophoresis in the presence of sodium dodecyl sulphate. Antibodies raised against the granulocyte enzyme also recognized the synovial gelatinase (fig. 4).

\section{Substrate specificity and enzyme activation}

The gelatinase from synovial fluid cells and from human neutrophil granulocytes displayed an identical behaviour against protein substrates: casein was a much poorer substrate than gelatin and bovine serum albumin was not hydrolysed by either enzyme (fig. 5). Both gelatinases were most effectively activated by trypsin, followed by 4-aminophenylmercury acetate. Activation with mersalylic acid was less efficient (fig. 6).

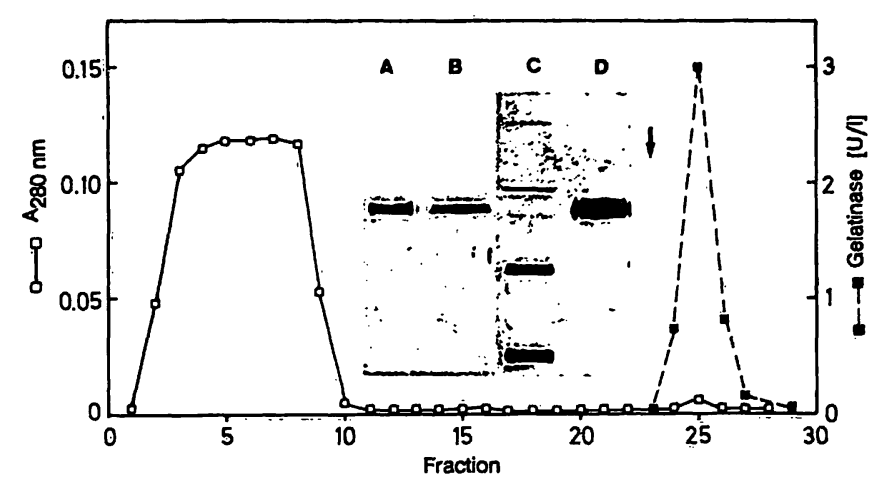

Fig. 4. Gelatin-Sepharose chromatography. The pool from UItrogel AcA 44 containing gelatinase activity was àpplied to a column of gelatin-Sepharose, equilibrated in 0.05 mol/1 Tris-HCl, pH 7.0, $0.2 \mathrm{~mol} / 1 \mathrm{NaCl}, 0.005 \mathrm{~mol} / 1$ $\mathrm{CaCl}_{2}, 0.5 \mathrm{~g} / 1$ Brij 35, $0.5 \mathrm{~g} / 1 \mathrm{NaN}_{3}$. Bound protein was eluted with $0.05 \mathrm{~mol} / 1$ Tris $-\mathrm{HCl}, \mathrm{pH} 7.0,1.0 \mathrm{~mol} / \mathrm{l} \mathrm{NaCl}$

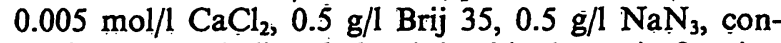
taining $50 \mathrm{ml} / 1$ dimethyl sulphoxide (arrow); fraction volume $4.8 \mathrm{ml}$. Insert: $8 \%$ polyacrylamide gel electro phoresis in the presence of sodium dodecyl sulphate and an immunoblot of synovia and polymorphonuclear leukocyte gelatinase.

Lane A $500 \mathrm{ng}$ polymorphonuclear leukocyte gelatinase;

Lane B $2.5 \mu \mathrm{g}$ synovia gelatinase;

Lane C molecular weight markers $\left(M_{\mathrm{r}}\right)$ : myosin (205000), $\beta$-galactosidase (116000), phosphorylase b $(97400)$, bovine albumin $(66000)$ and ovalbumin (45000);

Lane $\mathrm{D} 10 \mu \mathrm{g}$ synovia gelatinase.

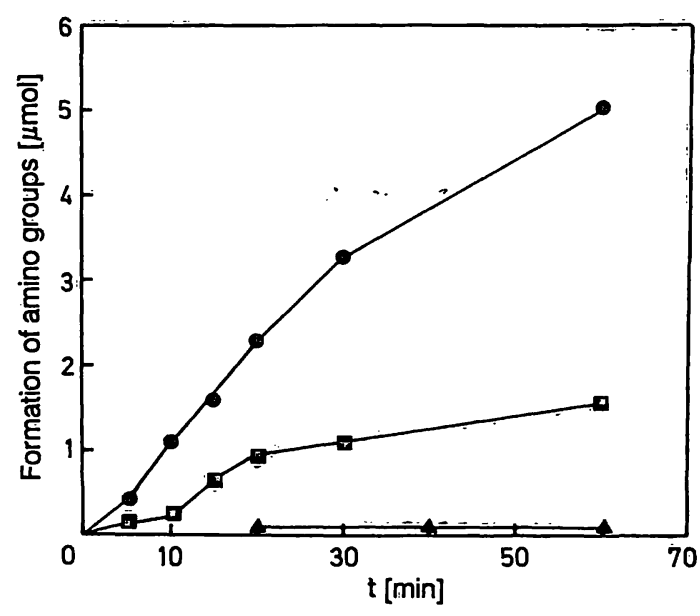

Fig. 5. Degradation of protein substrates. Equal concentrations of the substrates were incubated with gelatinase (enzyme : substrate ratio $1: 100$ ). Samples were removed at specified times and formation of amino groups was quantified by reaction with fluorescamine. Gelatin (solid circles), casein (solid squares) and bovine albumin (solid triangles).

Tab. 1. Purification of a $M_{\mathrm{r}}=92000$ gelatinase from the culture medium of rheumatoid synovial fluid cells.

\begin{tabular}{llllrr}
\hline Step & $\begin{array}{l}\text { Protein } \\
(\mathrm{mg})\end{array}$ & $\begin{array}{l}\text { Activity } \\
(\mathrm{mU})\end{array}$ & $\begin{array}{l}\text { Recovery } \\
(\%)\end{array}$ & $\begin{array}{l}\text { Specific activity } \\
(\mathrm{mU} / \mathrm{mg})\end{array}$ & $\begin{array}{c}\text { Purification } \\
\text { factor }\end{array}$ \\
\hline 1. Conc. medium & 84.0 & 17.0 & 100 & 0.2 & $(1)$ \\
2. Ultrogel AcA 44 & 3.9 & 15.3 & 90 & 3.9 & 19.6 \\
3. Gelatin-Sepharose & 0.036 & 12.0 & 71 & 333,0 & 1670.0 \\
\hline
\end{tabular}




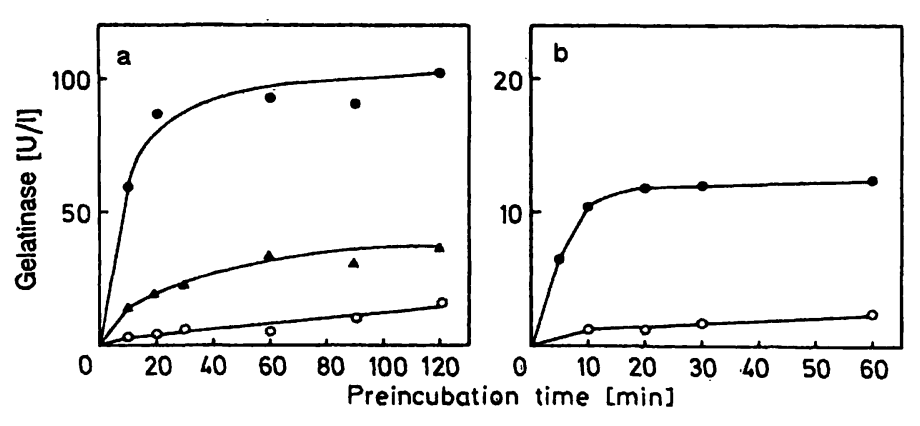

Fig. 6. Activation of latent gelatinase. Progelatinase from human synovial fluid cells was preincubated at $37^{\circ} \mathrm{C}$ in the presence of $10 \mu \mathrm{g}$ trypsin, $0.0015 \mathrm{~mol} / 1 \mathrm{l}$ 4-aminophenylmercury acetate and $0.001 \mathrm{~mol} / 1$ mersalylic acid, respectively, for varying periods of time. Before starting the reaction trypsin activity was stopped with $10 \mu \mathrm{g}$ aprotinin.

Substrates were

dinitrophenyl-peptide (a) and gelatin (b);

activators were:

trypsin (solid circles), 4-aminophenylmercury acetate (solid triangles) and mersalylic acid (open circles).

An identical pattern is obtained with latent gelatinase from human polymorphonuclear leukocytes.

\section{Discussion}

In the present study, a fully latent gelatinase was isolated from the culture medium of human rheumatoid synovial fluid cells. This enzyme had already been found in the synovia, together with other metalloproteinases hydrolysing the dinitrophenyl-peptide. However, after two or not later than three days in culture, all the proteolytic activity against gelatin or the dinitrophenyl-peptide, respectively, was due to the latent gelatinase, which could be detected for about two weeks in the culture.

The gelatinase had a relative molecular mass of $130000-150000$ on Ultrogel AcA 44 and displayed a molecular mass of about 95000 in polyacrylamide gel electrophoresis in the presence of sodium dodecyl sulphate. These data are in full agreement with those for human leukocyte gelatinase. Both enzymes showed identical behaviour with respect to substrate specificity and activation with trypsin or organomercurial compounds, such as 4-aminophenylmercury acetate and mersalylic acid. In contrast to other reports $(1,7)$, our data clearly indicate that trypsin is much more efficient than the organomercurials 4aminophenylmercury acetate and mersalylic acid. The gelatinase from synovial cells reacted with antibodies raised against human granulocyte gelatinase. Thus, the gelatinase we isolated from human rheumatoid synovial fluid cells is clearly a leukocyte-type of gelatinase.

Polymorphonuclear leukocytes, which can amount to more than $70 \%$ of all leukocytes in rheumatoid syn- ovial fluid (21), can be excluded as the source of this gelatinase, because under the conditions employed, polymorphonuclear leukocytes do not survive longer than maximally $24-48$ hours $(22,23)$. In accordance with the literature, we found $20 \%$ polymorphonuclear leukocytes after one day of culture. On the second day this cell type could not longer be detected in our monolayer cultures. For a more detailed discussion of the cell types found in cultures of synovial fluid cells see 1. c. (24).

Human monocytes/macrophages have been reported to secrete a latent metalloproteinase with a relative molecular mass of 92000 . Thus it can be concluded that the gelatinase described in this communication is secreted by monocytes/macrophages and/or macrophage-like synovial A cells.

Without stimulation, freshly isolated human monocytes from non-rheumatoid patients did not synthesize detectable amounts of this proteinase $(25,27)$. However in later culture media, when the monocytes had transformed to macrophages $(10-14$ th day in the culture), a gelatinase activity could be detected (26). A similar secretion behaviour can be expected from the macrophage-like A synovial cells, which are most probably derived from blood monocytes (28). At the start of the cell culture we found gelatin-degrading activity in the culture media and in the rheumatoid synovial fluid. If this activity had been contributed by blood monocytes, which constituted $80 \%$ of the cells in the early culture medium, these monocytes should have been in a stimulated state, possibly due to some factors present in the rheumatoid synovial fluid.

Fibroblasts, which are the predominant cell type in late cultures, produce a different type of gelatinase with a relative molecular mass of 72000 . Transformed human lung fibroblasts secrete the $M_{\mathrm{r}}=72000$ gelatinase as well as the $M_{\mathrm{r}}=92000$ gelatinase (8). However, in one case, it was reported that human gingiva fibroblasts secreted the typical fibroblast $M_{\mathrm{r}}$ $=72000$ gelatinase with minor quantities of the $M_{\mathrm{r}}$ $=92000$ gelatinase (25). The authors reported that the production of the $M_{\mathrm{r}}=92000$ gelatinase is not unusual in fibroblasts of other species than human.

Considering these various possibilities it seems difficult to determine exactly the cellular origin of the gelatinase in our cultures. However, we believe, in accordance with the observed time-dependent decrease of macrophages/monocytes in our cultures, that the gelatinase is most probably released by either the macrophage-like synovial A-cells or the activated blood monocytes. Fibroblasts are stimulated by macrophages to secrete the $M_{\mathrm{r}}=72000$ gelatinase (16). 
But in our system only the $M_{\mathrm{r}}=92000$ gelatinase could be detected, which is a surprising and in our opinion important observation in rheumatoid synovial cells, because both enzymes obey different regulatory mechanisms. The degree of tissue degradation depends ultimately on the ratio of active proteinases to proteinase inhibitors. Because the metalloproteinases, collagenase, stromelysin and gelatinase, are synthesized as inactive precursors, their activation is an important step in the regulated turnover of the extracellular matrix. With respect to activation and inhibition, there are marked differences between fibroblast and leukocyte gelatinase. Serine proteinases, such as trypsin, cathepsin $G$ and elastase, are potent activators of leukocyte gelatinase $(12,29-32)$. In contrast, the fibroblast gelatinase is not activated by these serine proteinases $(5,33)$. Both enzymes (leukocyte and fibroblast gelatinase) also show different behaviour against the tissue inhibitors of metalloproteinases (TIMP-1 and TIMP-2). While TIMP-1 exclusively binds to the latent leukocyte gelatinase, TIMP-

\section{References}

1. Mainardi, C. L., Seyer, J. M. \& Kang, A. H. (1980) Typespecific collagenolysis: A type V collagen-degrading enzyme from macrophages. Biochem. Biophys. Res. Commun. 97, 1108-1115.

2. Murphy, G., McAlpine, C. G., Poll, C. T. \& Reynolds, J. J. (1985) Purification and Characterization of a bone metalloproteinase that degrades gelatin and types IV and V collagen, Biochim. Biophys. Acta 831, 49-58.

3. Murphy, G., Reynolds, J. J., Bretz, U. \& Baggiolini, M. (1982) Partial purification of collagenase and gelatinase from human polymorphonuclear leukocytes. Biochem. J. 203, 209-221.

4. Hibbs, M. S., Hasty, K. A., Seyer, J. M., Kang, A. H. \& Mainardi, C. L. (1985) Biochemical and Immunological Characterization of the Secreted Forms of Human Neutrophil Gelatinase. J. Biol. Chem. 260, 2493-2500.

5. Collier, I. E., Wilhelm, S. M., Eisen, A. Z., Marmer, B. L., Grant, G. A., Seltzer, J. L., Kronberger, A., He, C., Bauer, E. A. \& Goldberg, G. I. (1988) H-ras Oncogene-transformed Human Bronchial Epithelial Cells (TBE-1) Secrete a Single Metalloprotease Capable of Degrading Basement Membrane Collagen. J. Biol. Chem. 263, 6579-6587.

6. Davies, M., Thomas, G. J., Martin, J. \& Lovett, D. H. (1988) The purification and characterization of a glomerular-basement-membrane-degrading neutral proteinase from rat mesangial cells. Biochem. J. 251, 419-425.

7. Murphy, G., Ward, R., Hembry, R. M., Reynolds, J. J., Kühn, K. \& Tryggvason, K. (1989) Characterization of gelatinase from pig polymorphonuclear leukocytes. Biochem. J. 258, 463-472.

8. Wilhelm, S. M., Collier, I. E., Marmer, B. L., Eisen, A. Z., Grant, G. A. \& Goldberg, G. I. (1989) SV40-transformed Human Lung Fibroblasts Secrete a 92-kDa Type IV Collagenase Which Is Identical to That Secreted by Normal Human Macrophages. J. Biol. Chem. 264, 17213-17221.

9. Seltzer, J. L., Eisen, A. Z., Bauer, E. A., Morris, N. P., Glanville, R. W. \& Burgeson, R. E. (1989) Cleavage of Type VII Collagen by Interstitial Collagenase and Type IV . Collagenase (Gelatinase) Derived from Human Skin. J. Biol. Chem. 264, 3822-3826.
2 exclusively binds to the latent fibroblast gelatinase in a $1: 1$ stoichiometry $(8,34-36)$. The activated enzymes are inhibited by both TIMPs. However, TIMP-1 is reported to have a more limited inhibitory potency against activated polymorphonuclear leukocyte metalloproteinases $(3,37 ;+38)$.

Fibroblast gelatinase plays a physiological role in remodelling of the extracellular matrix. The $M_{\mathrm{r}}$ $=92000$ gelatinase has the same capacity in degrading the components of the extracellular matrix. As this enzyme, however, is subjected to different control mechanisms, its secretion by rheumatoid synovial cells may be one of the factors responsible for the destructive processes in rheumatoid arthritis.

\section{Acknowledgement}

This work was supported by Opfermann Arzneimittel $\mathrm{GmbH}$, Wiehl, Germany and the Hoechst AG, Frankfurt am Main, Germany.

10. Sapolsky, A. I., Sheff, M. F., Matsuta, K., Howell, D. S., Moskowitz, R. W., Goldberg, V. M., Norby, D. P. \& Màlemud, C. J. (1983) 'Gelatinase-like' activity from articular chondrocytes in monolayer culture. Biochim. Biophys. Acta $762,227-231$.

11. Nakano, T. \& Scott, P. G. (1986) Purification and charac= terization of a gelatinase produced by fibroblasts from human gingiva. Biochem. Cell Biol. 64, 387-393.

12. Murphy, G., Bretz, U., Baggiolini, M. \& Reynolds, J. J. (1980) The latent collagenase and gelatinase of human polymorphonuclear neutrophil leukocytes. Biochem. J. 192, $517-525$

13. Mainardi, C. L., Hibbs, M. S., Hasty, K. A. \& Seyer, J. M. (1984) Purification and characterization of a type V collagen degrading metalloproteinase from rabbit alveolar macrophages. Collagen Relat. Res. 4, 479-492.

14. Vartio, T. \& Hovi, T. (1987) Polypeptide composition of human macrophage gelatinase. Acta Chem. Scand. B4I, $754-756$

15. Seltzer, J. L., Adams, S. A., Grant, G. A. \& Eisen, A. Z. (1981) Purification and Properties of a Gelatin-specific Neutral Protease from Human Skin. J. Biol. Chem. 256, 4662-4668.

16. Golds, E. E., Santer, V., Killackey, J. \& Roughley, P. J. (1983) Mononuclear cell factors stimulate the concomitant secretion of distinct latent proteoglycan gelatin and collagen degrading enzymes from human skin fibroblasts and synovial cells. J. Rheumatol. 10, 861-871.

17. Laemmli, U. K. (1980) Cleavage of Structural Proteins during the Assembly of the Head of Bacteriophage T4. Nature 227, 680-685.

18. Masui, Y., Takemoto, T., Sakakibara, S. \& Hori, H. (1977) Synthetic substrate for vertebrate collagenase. Biochem. Med. $17,215-221$.

19. Macartney, H. W. \& Tschesche, H. (1980) Latent collagenase from human polymorphonuclear leukocytes and activation to collagenase by removal of an inhibitor. FEBS Lett. 119, 327-332. 
20. Engelbrecht, S., Pieper, E., Macartney, H. W., Rautenberg, W., Wenzel, H. R. \& Tschesche, H. (1982) Separation of the Human Leukocyte Enzymes Alanine Aminopeptidase, Cathepsin G, Collagenase, Elastase and Myeloperoxidase. Hoppe-Seyler's Z. Physiol. Chem. 363, 305-315.

21. McCarty, D. J. (1989) Synovial Fluid. In: Arthritis and Allied Conditions, 11th edn. pp. 69-90, Lea \& Febiger, London.

22. D’Onofori, C. D. \& Paradisi, F. (1983) In vitro differentiation of human monocytes into mature macrophages during long-term cultures. Immunbiol. 164, 13-22.

23. Adams, D. O. (1979) Macrophages. In: Meth. Enzymol. 58, 494-506 (Jakoby, W. B. \& Pastan, I. H., eds.), Acad. Press Inc. London.

24. Mohamed-Ali, H., Hauer, R. W. \& Sörensen, H. (1991) Morphologie und Wachstumsverhalten von Synoviazellen in der Monolayer-Kultur. Z. Rheumatol. 50, 74-81.

25. Murphy, G., Hembry, R. M., McGarrity, A. M., Reynolds, J. J. \& Henderson, B. (1989) Gelatinase (type IV collagenase) immunolocalization in cells and tissues: Use of an antiserum to rabbit bone gelatinase that identifies high and low $\mathrm{M}_{\mathrm{r}}$ forms. J. Cell Sci. 92, 487-495.

26. Vartio, T., Hovi, T. \& Vaheri, A. (1982) Human Macrophages Synthesize and Secrete a Major 95,000-dalton Gelatin-binding Protein Distinct from Fibronectin. J. Biol. Chem. 257, 8862-8866.

27. Vartio, T. (1985) Gelatin-degrading activity secreted by cultured macrophages from human blood. Eur. J. Biochem. $52,323-329$.

28. Edwards, J. C. W. (1982) The origin of type A synovial lining cells. Immunbiol. 161, 227-231.
29. Dancewicz, A. M., Wize, J., Sopata, I., Wojtecka-Lukasik, E. \& Ksiezny, S. (1978) Specific and nonspecific activation of latent collagenolytic proteases of human polymorphonuclear leukocytes. In: Neutral Proteases of Human Polymorphonuclear Leukocytes (Havemann, K. \& Janoff, A., eds.) pp. 373-383, Urban \& Schwarzenberg, Inc. Baltimore-Munich.

30. Sopata, I. \& Wize, J. (1979) A latent gelatin specific proteinase of human leukocytes and its activation. Biochim. Biophys. Acta 571, 305-312.

31. Williams, H. R. \& Lin, T. Y. (1984) Human polymorphonuclear leukocyte collagenase and gelatinase. Int. J. Biochem. 16, $1321-1329$.

32. Vissers, M. C. M. \& Winterbourn, C. C. (1988) Activation of human neutrophil gelatinase by endogenous serine proteinases. Biochem. J. 249, 327-331.

33. Okada, Y. \& Nakanishi, I. (1989) Activation of matrix metalloproteinase 3 (stromelysin) and matrix metalloproteinase 2 ('gelatinase') by human neutrophil elastase and cathepsin G. FEBS Lett. 249, 353-356.

34. Stetler-Stevenson, W. G., Krutzsch, H. C. \& Liotta, L. A. (1989) Tissue Inhibitor of Metalloproteinases (TIMP-2). J. Biol. Chem. 264, 17374-17378.

35. Goldberg, G. I., Marmer, B. L., Grant, G. A., Eisen, A. Z., Wilhelm, S. \& He, C. (1989) Human 72-Kilodalton type IV collagenase forms a complex with a tissue inhibitor of metalloproteinases designated TIMP-2. Proc. Natl. Acad. Sci. USA 86, 8207-8211.

36. Kolkenbrock, H., Orgel, D., Hecker-Kia, A., Noack, W. \& Ulbrich, N. (1991) The complex between a tissue inhibitor of metalloproteinases (TIMP-2) and 72-kDa progelatinase is a metalloproteinase inhibitor. Eur. J. Biochem. 198, $775-781$.

37. Hipps, D. S. \& Murphy, G. (1988) Studies on human fibroblast gelatinase. Biochem. Soc. Trans. 16, 893 .

PD Dr. Norbert Ulbrich

Freie Universität Berlin

Institut für Biochemie

Ostpreußendamm 111

W-1000 Berlin 45

Germany 
